

\title{
The Western Balkans in the Transatlantic Security Context: Where Do We Go from Here?
}

\author{
OYA DURSUN-ÖZKANCA*
}

\begin{abstract}
The Western Balkans has traditionally held vital geostrategic importance for European and transatlantic security. Ever since the 1990s, the $E U$ and the NATO have maintained an active presence in the region, and pursued goals of stability and peace. Since the 2000s, the Euro-Atlantic actors have sought an eventual integration of the countries in the region into transatlantic structures. This article provides a comprehensive analysis of the contemporary situation in the Western Balkans, examining the regional countries' prospects for Euro-Atlantic integration and the implications of the latest developments for transatlantic security. It makes the argument that NATO accession acts as a prelude to eventual EU accession, ensuring that the countries stay the course of engaging in reforms and contributing to Euro-Atlantic security while confirming their commitment to democracy.
\end{abstract}

\section{Introduction}

he Western Balkans has traditionally held vital geostrategic importance for European and transatlantic security. The region has experienced great power competition for centuries and typically been referred to as the 'powder keg of Europe.' With the dissolution of Yugoslavia, the region witnessed serious instability and bloodshed in the form of civil wars and ethnic conflicts. Ever since the 1990s, both the European Union (EU) and the North Atlantic Treaty Organization (NATO) have played an active role in the Western Balkans, significantly contributing to the efforts to establish peace and stability. Besides playing an active role in peacekeeping and peacebuilding missions and providing economic and military aid, ever since the 2000s, the two organizations have offered a membership trajectory to the countries in the region. In fact, in 2004, Slovenia first become a NATO and then an EU member. In 2009, Albania and Croatia became members of NATO. Four years later, in 2013, Croatia became an EU member state. Finally, in 2017, Montenegro became the $29^{\text {th }}$ member of NATO. 


\section{Even though integration into the EU and NATO has remained a priority for the countries in the region, the reforms, for the most part, have stalled, and the EU's political attention to the Western Balkans has been diverted elsewhere}

North Macedonia has been an EU candidate since 2005, Montenegro since 2010, Serbia since 2012, and Albania since 2014. Bosnia and Herzegovina and Kosovo each have a Stabilization and Association Agreement (SAA) with the EU. Kosovo signed it on October 27, 2015, and Bosnia and Herzegovina concluded a Framework Participation Agreement (FPA) in 2015. Bosnia and Herzegovina sub-

sequently submitted its EU membership application on February 16, 2016. At the timing of the writing of this article, the European Commission was in the process of preparing an opinion on the country's membership application. Kosovo and Bosnia and Herzegovina are considered to be potential candidate countries for EU membership, despite the long and arduous road ahead for both.

However, the Euro-Atlantic integration of the Western Balkans is far from being complete. Montenegro and Serbia are the only two Western Balkan countries that are in accession negotiations with the EU. EU accession negotiations with Montenegro were opened in June 2012. To date, 32 negotiating chapters have been opened, of which three have been provisionally closed. In Serbia's accession negotiations with the EU, 16 out of 35 chapters were opened, two of which have been provisionally closed. The remaining countries, Albania, North Macedonia, Kosovo, and Bosnia and Herzegovina, have still not opened accession negotiations with the EU. Albania and North Macedonia are regarded as the next two countries in line for opening accession negotiations, as long as they show progress in the fight against corruption and in reforming their judicial systems. An intergovernmental conference with participation from Albania and North Macedonia is expected by the end of 2019.

On the NATO front, there are two Western Balkan countries, Bosnia and Herzegovina and North Macedonia, that have indicated their willingness to join the Alliance. Serbia joined NATO's Partnership for Peace (PfP) Program in December 2006. PfP was initiated in 1994 in order to allow "participants to develop individual relationship with NATO, choosing their own priorities for cooperation, and the level and pace of progress. ${ }^{1} \mathrm{PfP}$ is seen by some as a de facto waiting room for ultimate NATO membership. Nevertheless, due to its recent history with NATO and close ties with Russia, Serbia has not declared an intention of becoming a NATO member. Kosovo similarly has not declared any aspiration of becoming a PfP Program or NATO member. 
The region has continued to maintain its vital strategic importance for Euro-Atlantic actors, first and foremost due to the direct implications of regional stability for European and transatlantic security, stability, and peace. Put simply, due to its geographical proximity and the ties that different actors have with countries within and outside the EU, any instability in the region would spill over and adversely affect Euro-Atlantic interests. This was true in the 1990s and is still true today. Both the EU and NATO still seek to preserve peace and stability in the Western Balkans. A significant change from the early 1990s is the membership trajectory that both institutions offer to the countries in the region. Therefore, integration into the transatlantic community has been added to the goals of preserving peace and stability in the region.

Having said that, from 2004 to 2014, there has been little sustained, high-level Euro-Atlantic engagement in the region, as the EU and NATO were each preoccupied with other pressing agenda items, such as the Eurozone crisis, the immigration crisis, Brexit, Russian aggression, instability in the Middle East and North Africa, and the rise of nationalism/populism. Consequently, even though integration into the EU and NATO has remained a priority for the countries in the region, the reforms, for the most part, have stalled, and the EU's political attention to the Western Balkans has been diverted elsewhere. Despite this, it is important to note that the EU and NATO still continued to maintain peace missions in the region during this time period.

Against the background of a strategic attention vacuum, the region has experienced a number of serious setbacks over the past decade in economic development, democratization, and rule of law, and an overall slowdown in the reform processes toward EU and NATO integration. In the economic realm, markets continue to bear the legacy of the communist era and have proven difficult to transition into functioning capitalist economies. Hence, many remain inefficient and have low competitiveness, low productivity, and a high degree of informality. ${ }^{2}$ Even though according to the latest World Bank data there have been some improvements in terms of unemployment figures in the region, these figures still lag considerably behind international standards, and the young and educated are emigrating in search of better opportunities abroad, contributing to brain-drain and loss of human capital. Notably, about one-third of the region's legal residents live outside the region. ${ }^{3}$ GDP growth in the region declined to 2.5 percent in 2017, due primarily to slower growth in Bosnia and Herzegovina, North Macedonia, and Serbia. ${ }^{4}$ There are large external deficits and public debt, as well as infrastructural deficiencies, as noted in most, if not every country's progress reports. Additionally, intervention by outside actors, such as Russia, China, Iran, and Saudi Arabia, have raised concerns on the part of the transatlantic allies, as these countries were perceived to counter the influence of the EU and NATO. 
Especially due to the countries' low likelihood of EU accession in the foreseeable future, there seems to be a power vacuum that outside actors are seeking to fill
From 2014 onwards, the attention of the transatlantic actors has consequently returned to the Western Balkans, as the EU recognized that tensions are brewing, economies are stalling, outside actors are intervening, and there is a significant deviation from democratic values and the rule of law in the region. In addition to a grave recognition of the seriousness of the problems experienced in the region, the renewed interest of the Euro-Atlantic actors may also be attributed to the successive migration/refugee waves the region has received from the Middle East and North Africa. As the countries in the Western Balkans region functioned as major transit countries for refugees and immigrants en route to the EU, the urgency of the refugee crisis and the pragmatic need to contain it command immediate attention to the Western Balkans. ${ }^{5}$

As mentioned above, the peace, stability, and welfare of the Western Balkans have direct implications for the stability of the Euro-Atlantic area. A case in point is the phenomenon of foreign fighters that join terrorist organizations in the fight against the Western allies. While the numbers of foreign fighters are quite low, the per capita statistics are high, given the relatively small population sizes of the Western Balkan countries. Moreover, the fact that the region is located along alternative energy routes adds to the significance of the region for European nations as they aspire to reduce their dependence on Russian energy. Adding to the concerns are the disturbing debates over a possible agreement for a land swap or "border correction" between Kosovo and Serbia, and the implications this would carry for peace and stability in the region. Consequently, the strategic importance of the region for transatlantic security has further increased.

There is still much uncertainty and stalemate in terms of the transatlantic integration of the countries in the region. Especially due to the countries' low likelihood of EU accession in the foreseeable future, there seems to be a power vacuum that outside actors are seeking to fill. A unique aspect of the current study is that it provides an analysis of the latest developments in the Western Balkans, examining the implications of the stability in the region for transatlantic security. Another unique aspect is the argument that NATO accession acts as a prelude to an eventual EU accession, ensuring that the countries stay the course of engaging in reforms and contribute to Euro-Atlantic security while confirming their commitment to democracy. ${ }^{6}$

What makes this article unique is its attempt at providing a conceptual and theoretical framework for understanding the involvement of transatlantic actors 
in the security of the Western Balkans. It seeks to analyze the causes behind the differences in the impact of conditionality powers between the EU and NATO. Accordingly, the article first provides a historical overview of transatlantic integration attempts in the region. It then provides a literature review, followed by an examination of recent developments in the region. Subsequent to a discussion of the implications of the status quo for the Western Balkan countries' prospects for integration into transatlantic security infrastructures, this article examines in detail the revival of the EU's attention to the region. In addition to surveying the Western Balkans-related causes for renewed transatlantic attention, this article also investigates EU-related factors to explain the stalemate in the transatlantic integration processes of the countries in the region. It finally discusses the repercussions of these prospects for transatlantic security.

Overall, for the Western Balkan countries that are currently members of both the EU and NATO, i.e. Slovenia and Croatia, NATO accession has proven to be relatively quicker than EU accession. In fact, this article argues that NATO accession helps facilitate the EU integration prospects of Western Balkan countries, as it necessitates significant structural reforms that are necessary for conducting further reforms on EU membership criteria. In that sense, this article holds that NATO accession helps prepare countries in the region for EU accession and reinforces their accession into the EU.

\section{A Historical Overview of Transatlantic Integration Attempts}

The transatlantic integration prospects of some of the Western Balkan countries go all the way back to 1995, when North Macedonia joined NATO's PfP Program. Shortly thereafter, Slovenia applied for EU membership in 1996. At the 2003 Thessaloniki Summit of the European Council, the countries in the Western Balkans received their first recognition from the EU that "the future of the Balkans is within the European Union." Over the course of the next decade, the EU welcomed 13 new members, including two that were part of the former Yugoslavia: ten in 2004, ${ }^{8}$ two in 2007, and one in $2013 .{ }^{9}$ This created what is frequently referred to as enlargement fatigue in the EU, making EU members more reluctant to accept new members into the Union. Accordingly, since 2010, the EU has mainly diverted its attention away from the Western Balkans.

NATO, on the other hand, has done a relatively better job of keeping an enlargement perspective at its core and has been rather immune to enlargement fatigue when compared to the EU. At its Riga Summit in 2006, NATO declared that "Euro-Atlantic integration, based on solidarity and democratic values, remains necessary for long-term stability" for the Western Balkans. ${ }^{10}$ NATO's "open door policy" was underlined at the Bucharest Summit in 2008, when 
Had NATO not continued its enlargement vision, it would have been even more challenging for the Western Balkan countries to remain committed to a European and transatlantic vision
NATO reemphasized its "goal of a Europe that is whole, free, and at peace." ${ }^{11}$

In that sense, it is possible to argue that the prospect of NATO accession keeps the democratic and market reforms going in the region, helping contribute to the prospects of EU membership. In all successful accession cases in the Western Balkans, NATO accession has preceded EU accession. This trend is expected to continue in the future too, as Albania has been a NATO member since 2009, and is still an EU candidate country. Once the Republic of North Macedonia becomes a NATO member, its EU membership is expected to take a longer timeframe, but to materialize eventually.

However, this trend has sparked criticism from civil society organizations that the Euro-Atlantic actors have long preferred regional stability and security over democratization. The fact that, for the countries in the region, their NATO accession precedes EU accession confirms the argument that NATO is more concerned with the criteria that strengthen military capabilities and preparedness in the Euro-Atlantic region rather than shared values and democratization. It is nevertheless important to recall that EU and NATO accession processes are two-way streets, and that the outcome depends as much on the internal factors of the countries in the Western Balkans as it does on the priorities and the political will of these institutions.

Many internal factors have prevented engagement in the constructive reform processes that would enable successful integration into the EU and NATO. This means that the elites that were already benefiting from the existing system have become less willing to change the status quo and fight against organized crime and corruption. The region has consequently experienced a surge of illiberal forces. There is a troubling track record on good governance, transparency, accountability, transitional justice, and security sector reform. There is a culture of impunity. Realizing their diminishing prospects for getting into the EU, many Western Balkan countries have started searching for alternative venues, while also stalling their reform processes towards EU membership.

One of the major roadblocks to Euro-Atlantic integration is the democratic backsliding experienced by many countries in the region. There is a rising populist wave in the region, which creates additional tensions between different countries in the region, seriously jeopardizing regional stability and peace, and making pundits and scholars wary of renewed ethnic conflicts. As a corollary to the rising populism, the political elites in the region have increasingly re- 


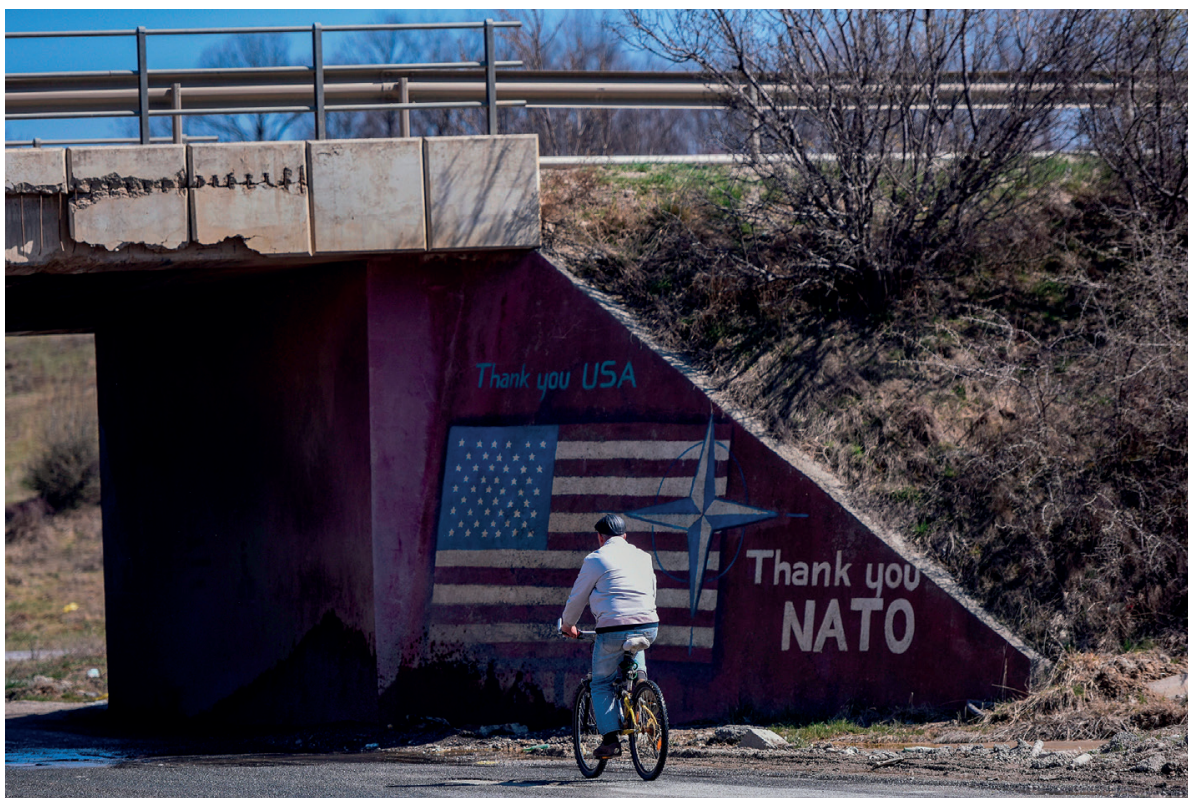

alized that pursuing irredentist claims pays off electorally. In a region that is traditionally referred to as the powder keg of Europe, such trends cause grave concern in transatlantic circles.

To make an already complex situation more intricate, when the Juncker Commission came into power in 2014, the European Commission announced that there would be no new round of enlargement under its tenure. Much to the dismay of the candidate countries and potential candidate countries, the Commissioner for Enlargement position was eliminated in the reorganized Commission structure. This has led to a sense of inertia in the region and undermined the credibility of EU accession prospects and the conditionality power of the EU. ${ }^{12}$ Had NATO not continued its enlargement vision, it would have been even more challenging for the Western Balkan countries to remain committed to a European and transatlantic vision.

\section{Literature Review}

International Organizations (IOs) like the EU and NATO fulfill many diverse functions, including democratization mechanisms, such as "conditionality," 13 the sharing of information on "best practices," 14 regulating the conduct of states through the diffusion of norms, ${ }^{15}$ "socializing" states, ${ }^{16}$ engaging in conflict management, ${ }^{17}$ taking over classical state functions in post-conflict situations, delivering essential services and providing security, ${ }^{18}$ and providing as-
A man rides his bicycle past a graffiti reading "Thank You NATO" and featuring the U.S. flag near the village of Stagove, Kosovo. ARMEND NIMANI / AFP / Getty Images 
sistance with Security Sector Reform. ${ }^{19}$ "Orchestration" -the coordination and coherence of the response- between different IOs is crucial for the outcome of reforms in post-conflict environments. ${ }^{20}$ Promoting sustained and coherent efforts to maintain stability and security are therefore crucial for a successful transformation of post-conflict contexts. This is especially the case in the Western Balkans, where the EU and NATO conditionality created incentives for reform and democratization.

There is disagreement between proponents of neo-realism, neo-liberalism, and constructivism on the roles played by international institutions. Neo-realism rarely acknowledges the independent role played by IOs, and when it does, it does not place emphasis on the benefits of having them and typically argues that they reflect power relations between nation states. ${ }^{21}$ For neo-realism, all actors except nation states are irrelevant in the study of international politics.

Neo-liberalism, on the other hand, emphasizes the role of IOs in fostering international cooperation and reducing security dilemmas. ${ }^{22}$ It highlights the benefits of having IOs, including the provision of information, the promotion of international norms, and the reduction of transaction costs in mitigating anarchy in the international system. ${ }^{23}$ Some neo-liberals focus on the role of IOs in supporting democracy via the construction of domestic constitutional mechanisms and the sharing of information on best practices. ${ }^{24}$ Even though neo-liberalism emphasizes the benefits of having IOs, it does so mostly from the perspective of nation states. It holds that IOs serve state interests as they provide a less costly and more convenient tool than direct state intervention. For neo-liberals, states are the main agents; they create structures consisting of norms and institutions for their own convenience. ${ }^{25}$

Constructivism has a more flexible take on the significance of non-state actors such as IOs. It emphasizes how ideas and identities are created, and how they evolve. According to constructivists, IOs play an independent role in international politics; ${ }^{26}$ they learn through their experiences in the field and adjust their organizational structures and mission mandates accordingly. ${ }^{27}$ Constructivists hold that IOs learn how best to cooperate with one another throughout their interactions in the field, and that this evolutionary process takes some time..$^{28}$

The implementation of the "comparative advantage principle" 29 by IOs through specialization on delivering services that they perform best ${ }^{30}$ is vital for the effectiveness and efficiency of the transatlantic community's efforts in the Western Balkans. This article argues that both NATO and the EU, as IOs, have developed and maintained a niche, where they focus on delivering the particular type of service they accomplish best when compared to the other institution, and use that comparative advantage. It makes the argument that 
in the Western Balkans, NATO serves the purpose of addressing the most immediate need to secure its southeastern flank, provides regional security, and establishes and protects the territorial integrity of its member states, whereas the EU addresses the need to engage in more comprehensive economic and political reforms. Therefore, NATO membership prospects help accomplish technical and military reforms, such as placing security forces under democratic control, whereas EU membership prospects

seek to achieve democratic political and economic reforms in the region. Both visions complement one another. In that sense, NATO and EU conditionality reinforce one another.

\section{Recent Developments in the Region}

In North Macedonia, under the ten-year term of former Prime Minister Nikola Gruevski, there were many violations of the rule of law and civil and political liberties. There were widespread demonstrations against the government, which eventually resulted in a political crisis and the declaration of early elections in 2016. Ever since the election of Prime Minister Zoran Zaev to power in 2016, there has been a positive reform momentum.

North Macedonia's EU membership prospects have been stalled up until recently due to the name dispute with Greece, which has been going on for almost three decades. Consequently, the EU members recognized North Macedonia under the name 'the Former Yugoslav Republic of Macedonia' (FYROM), instead of under its previous constitutional name, the Republic of Macedonia. Even though the country submitted its application for membership to the EU in 2005, it was vetoed by Greece, which argued that the use the 'Republic of Macedonia' implied territorial claims on its northern province, and ignored its cultural heritage and identity that goes all the way back to Alexander the Great.

On that front, there have been notable positive developments since the summer of 2018. In June 2018, under the mediation of the United Nations, the Prespa Agreement was signed between the leaders of the two countries, with the parties agreeing on a new name for the country -the Republic of North Macedonia. In January 2019, the Parliament of North Macedonia adopted a number 


\section{As was the case with the name dispute resolution between North Macedonia and Greece, the Brussels Dialogue is a high-level, elite-driven process, suffering from significant information gaps between elites and public in both Serbia and Kosovo}

ready to prepare recommendations to open up accession negotiations with $\mathrm{Al}$ bania and North Macedonia once the necessary conditions are fulfilled. Consequently, falling short of taking a decision to open up accession negotiations, the European Council announced in June 2018 that June 2019 is the projected date for opening accession negotiations with Albania and North Macedonia if the two countries make progress on reforms in the fight against corruption and improving their judicial systems.

Ever since 2011, the EU has been sponsoring normalization talks between Kosovo and Serbia. Normalization of bilateral relations is a prerequisite for both countries' EU accession. The Brussels Dialogue, facilitated by the EU, aims at resolving long-standing issues between the two countries and advancing their EU integration. In April 2013, the two sides signed the Brussels Agreement, which establishes mutual agreement on politically sensitive issues such as security, rule of law, local authorities in the Serbian-inhabited parts of Kosovo, and the judiciary. It called for the creation of the Association/Community of Serb majority municipalities and the reintegration of the north of the Ibar River into Kosovo. However, the Agreement has proven very difficult to implement and has caused significant tensions between the two parties due to nationalist backlash against its content. In particular, the Association/Community of Serb majority municipalities was regarded by many in Kosovo as a threat against the territorial integrity of the country. Throughout its eight-year lifetime, there have been many ups and downs in the process. In 2018, the assassination of Oliver Ivanović, a Kosovo Serb politician from north Kosovo, and the arrest of the Serbian government official Marko Đurić by Kosovo police in north Mitrovica have added strain to the Brussels Dialogue. Additionally, as was the case with the name dispute resolution between North Macedonia and Greece, the Brussels Dialogue is a high-level, elite-driven process, suffering from significant information gaps between elites and public in both Serbia and Kosovo. Aggravating rhetoric has been used by both sides in order to achieve electoral gains. ${ }^{33}$

In summer 2018, there were talks of a possible land swap between Serbia and Kosovo; exchanging the mainly Serbian-inhabited north of the Ibar River in Kosovo with the mainly Albanian-inhabited Presevo Valley in southern Serbia. 
Even though, initially there was not much vocal opposition to the idea with the exception of German Chancellor Merkel, later on, both the EU and NATO urged the parties to refrain from a redefinition of borders between Kosovo and Serbia, as it would open a Pandora's box in the region, inciting others to demand border changes along ethnically homogenous lines, and undermining the territorial integrity of other countries in the region, such as Bosnia and Herzegovina, North Macedonia, and Montenegro. It might also jeopardize the security of the remaining ethnic minorities within the newly defined borders, potentially causing massive population movements across borders.

On the topic, the latest Progress Report of the European Commission on Serbia notes that Serbia remains engaged in the dialogue, even though it "needs to make further substantial progress on the implementation of existing agreements and contribute to the establishment of circumstances conducive to" full normalization. ${ }^{34}$ It also emphasizes that there are ongoing problems with corruption, organized crime, government control over the media, and the justice system in Serbia. The normalization negotiations were reinitiated by Brussels in July 2018, but since then, the issue of Kosovo's imposition of 100 percent tariffs on imported Serbian goods in response to Serbia's veto of Kosovo's membership into INTERPOL created additional strains in the EU-sponsored talks. ${ }^{35}$ Consequently, Serbia walked away from the normalization negotiations.

Adding to the complexity of the sovereignty issue is the existence of five EU member states, Cyprus, Greece, Romania, Slovakia, and Spain which do not recognize Kosovo's independence. All but Cyprus are NATO members; their stance presents a potential barrier against Kosovo's NATO future. Kosovo is the only remaining Western Balkan country without a visa liberalization framework with the EU. In July 2018, the European Commission concluded that Kosovo had fulfilled all the benchmarks for visa liberalization, however, the European Council has been reluctant to grant visa liberalization to the country before the holding of European Parliament elections in May 2019.

In 2016, there was a Russian coup plot to remove Montenegro's pro-NATO Prime Minister from power. The coup attempt was thwarted by the authorities and the country became a NATO member in 2018. This served as a good signal to other countries in the region that integration in the transatlantic infrastructures was still a possibility.

Besides PfP, NATO also launched a Membership Action Plan (MAP) in April 1999, which provides "advice, assistance and practical support tailored to the individual needs of countries wishing to join the Alliance." 36 The Republic of North Macedonia has been in the MAP program since 1999. Countries that are in the MAP are required to submit annual reports on their preparations 
on political, economic, defense, resource, security, and legal aspects, for possible future NATO membership. The program provides "focused and candid feedback on aspirant countries' progress on their programmes" at the political and technical levels. ${ }^{37}$

In 2010, Bosnia and Herzegovina received an invitation from NATO to join the MAP. The MAP goes beyond the PfP Program and is intended to give advice and support to countries that have a clear goal of joining NATO. Nevertheless, the Alliance, in 2010, declined to activate the MAP until all conditions were met. Republika Srpska (RS) is against

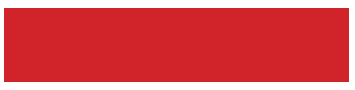

While it created a multi-ethnic state, the Dayton Agreement institutionalized the ethnic divisions within the country NATO membership, due to its fresh memories of the NATO-led air strikes against Serbs in the 1990s. NATO membership as well as the activation of the MAP requires a successful resolution of the issue of the registration of military property at the state level. As of now, military property is under the control of Bosnia's two entities, RS and the federation. Given the structure that was established by the Dayton Agreement, it is hard to have a centralized governance structure in Bosnia and Herzegovina, which hampers the prospects of engaging in successful reforms toward Euro-Atlantic integration. In that sense, while it created a multi-ethnic state, the Dayton Agreement institutionalized the ethnic divisions within the country. Despite eight years of inactivity and the continued veto from RS, in December 2018, NATO foreign ministers agreed to activate the MAP and invited Bosnia to submit its first annual national program of political, economic, and defense reforms to bring the country in line with NATO standards.

\section{The EU's Renewed Interest in the Western Balkans}

The EU is still the most important actor in the region. Launched in 1999, EU's Stabilization and Association Process (SAP) is a comprehensive framework for the countries in the region for their accession into the EU with three main goals: the stability of SAP countries and their swift transition to market economies, enhanced regional cooperation, and eventual membership in the EU. The Instrument for Pre-Accession (IPA) Funding adopted by the EU in 2006 consists of $€ 11.5$ billion and is intended as assistance for transition and institution-building, regional integration and development, human resources, and rural development. IPA II covers the period between 2014 and 2020 and has a budget of $€ 12$ billion. ${ }^{38}$ Different than IPA I, it includes regional cooperation initiatives. Moreover, trade agreements between the EU and a number of Western Balkan countries have had a further, positive impact on the economies of both sides. 
Although the Berlin Process

came to an end with the

2018 London Summit, there

is a strong commitment to

continuing this process beyond

2018. In May 2017, German

Foreign Minister Sigmar

announced the Berlin Plus

agenda to be a continuation of the Berlin Process
The EU accession prospects have already facilitated economic and political reforms in the Western Balkan candidate and potential candidate countries and improved regional cooperation and integration, as clearly seen in the case of the visa liberalization process. All Western Balkans countries but Kosovo now have visa-free travel programs with the EU, contributing to exchanges between the two regions. As reported by the European Council in 2018, in 2016, the region's total trade with the EU was

over $€ 43$ billion. EU companies have accounted for over $€ 10$ billions of FDI in the region since 2013, making the EU the largest contributor to FDI in the Western Balkans. ${ }^{39}$

Despite a period of strategic vacuum and lack of attention to the region, German Chancellor Angela Merkel initiated a new process, called the Berlin Process, by organizing the Western Balkans Summit in Berlin in 2014, to emphasize that the future of the Balkans remains within the EU. The goals of the Berlin Process were to emphasize the vision of the Western Balkans' EU integration, improve regional connectivity and cooperation, and encourage the region's structural reforms for an eventual EU accession. European leaders have frequently emphasized that the Berlin Process is complementary to $\mathrm{EU}$ accession, rather than an alternative. Under its framework, a total of five conferences were held: the 2014 Berlin Summit, the 2015 Vienna Summit, the 2016 Paris Summit, the 2017 Trieste Summit, and the 2018 London Summit. At the Vienna Summit in 2015, the European perspective toward the region and the resolution of open bilateral issues impacting the European integration process were put on the table. In line with the Berlin Summit, the Vienna Summit continued endorsing connectivity among the peoples of the region, especially among the youth population. At the Paris Summit in 2016, the parties reconfirmed their commitment to abstain from misusing bilateral issues in the EU accession process. The Trieste Summit in 2017 included three regional cooperation initiatives: connecting people with a special emphasis on youth, connecting economies through a Regional Economic Area, and connecting infrastructure through a Transport Community Treaty. ${ }^{40}$ At the London Summit in 2018, the parties emphasized the importance of connectivity, security coordination, regional cooperation, good neighborly relations, and youth and civil society. The Western Balkans countries have signed the Joint Declaration on the Principles of Information-Exchange in the Field of Law Enforcement and 
endorsed the Roadmap for a Sustainable Solution to Illegal Possession, Misuse and Trafficking of Small Arms and Light Weapons and their Ammunition in the Western Balkans document. ${ }^{41}$ The London Summit also indicated the UK's continued involvement in the region, even following Brexit. At the London Summit, the European Commission announced the establishment of a new $€ 150$ million guarantee instrument, building on the pledge of $€ 190$ million to enhance transport connectivity, and also the signature of the Transport Community Treaty Headquarters agreement, the work by Italy on an anti-corruption initiative which was launched at the 2017 Trieste Summit. ${ }^{42}$

Although the Berlin Process came to an end with the 2018 London Summit, there is a strong commitment to continuing this process beyond 2018. In May 2017, German Foreign Minister Sigmar announced the Berlin Plus agenda to be a continuation of the Berlin Process.

In February 2018, the European Commission announced its new and ambitious strategy for the region, titled "A Credible Enlargement Perspective for and Enhanced EU Engagement with the Western Balkans," which is also known as the EU Strategy for the Western Balkans. A few months after the announcement of the Strategy document by the European Commission, in May 2018, the European Council adopted the Strategy. ${ }^{43}$ The Strategy document set a target date of 2025 for Serbia and Montenegro's accession, providing a more credible prospect for the countries to join the EU. It also reiterated the commitment of the EU for enlargement to include the remaining countries of the Western Balkans. It also outlined six flagship initiatives that the EU would engage in to support the transformation of the region in regard to the rule of law, security and migration cooperation via joint investigation teams and the European Border and Coast Guard, socio-economic development, transport and energy connectivity, digital agenda, reconciliation, and good neighborly relations. The Strategy document envisions the enlargement of the EU's Energy Union to the region, and increased connectivity between the EU and the Western Balkans through lowering roaming charges and rolling out broadband. ${ }^{44}$

The novel idea in the Strategy document is that it foresees the EU taking on a more active role in political dispute resolution across the region and upgrading infrastructure as part of the Berlin Process. ${ }^{45}$ Therefore, it is possible to conclude that that the EU appears to have drawn key lessons from its previous enlargement rounds, such as the admission in 2004 of Cyprus without a resolution of the conflict between the Turkish and Greek Cypriots, which practically eliminated all incentives for the Greek Cypriots to reach a compromise. In order to ensure that the prospects of the resolution of bilateral conflicts are not hampered, the Union now asks for the resolution of bilateral or multilateral disputes before the countries in the Western Balkans join the EU. 
The overall strategy that animates NATO when it comes to its Western Balkans policies is to keep Russia and other third parties' influence limited in the region, while making sure that the Euro-Atlantic allies' security remains intact
Similarly, the document illustrates that the Union now sets higher bars for the current candidate countries and does so earlier on in the process, drawing on lessons learned from Bulgaria and Romania's poor track record on the rule of law, years after these two countries were admitted into the EU. The Strategy document emphasizes that the enlargement to include the Western Balkans is a "merit-based process,"

which signifies that even though the EU provides a roadmap for the countries in the region for membership, each country still has to fulfill the Copenhagen criteria and be approved by all members of the EU for membership. ${ }^{46}$ This seems to add to the credibility problem, as the EU accession process is seen as an open-ended one.

\section{Conclusion: Projections for the Future}

The Western Balkans "remains the last non-integrated part of Europe" 47 and an important investment for European and transatlantic security. The EU and NATO encourage regional cooperation, visa-free travel, and technical exchanges on issues ranging from free trade and anti-corruption measures to defense cooperation. It is nevertheless true that accession should not be the litmus test for whether or not the EU and NATO are bringing the Western Balkans closer to the transatlantic security community.

Through its Strategy document in 2018, the EU has signaled that it recognizes the strategic significance of the region, and brought the countries of the region closer to EU membership. The overall strategy that motivates the EU when it comes to the Western Balkans is to keep the region's European and transatlantic perspective, and encourage economic and political reforms in the region. The overall strategy that animates NATO when it comes to its Western Balkans policies is to keep Russia and other third parties' influence limited in the region, while making sure that the Euro-Atlantic allies' security remains intact. Through its continued accession process, NATO has been consistently signaling that the region holds strategic importance for transatlantic allies, and is committed to keeping the countries in the region in the transatlantic orbit. It is, therefore, possible to argue that NATO accession prospects helps reinforce EU accession prospects for the countries in the region, while preventing the countries from drifting apart from transatlantic actors due to enlargement fatigue and other crises within the EU. In that sense, 


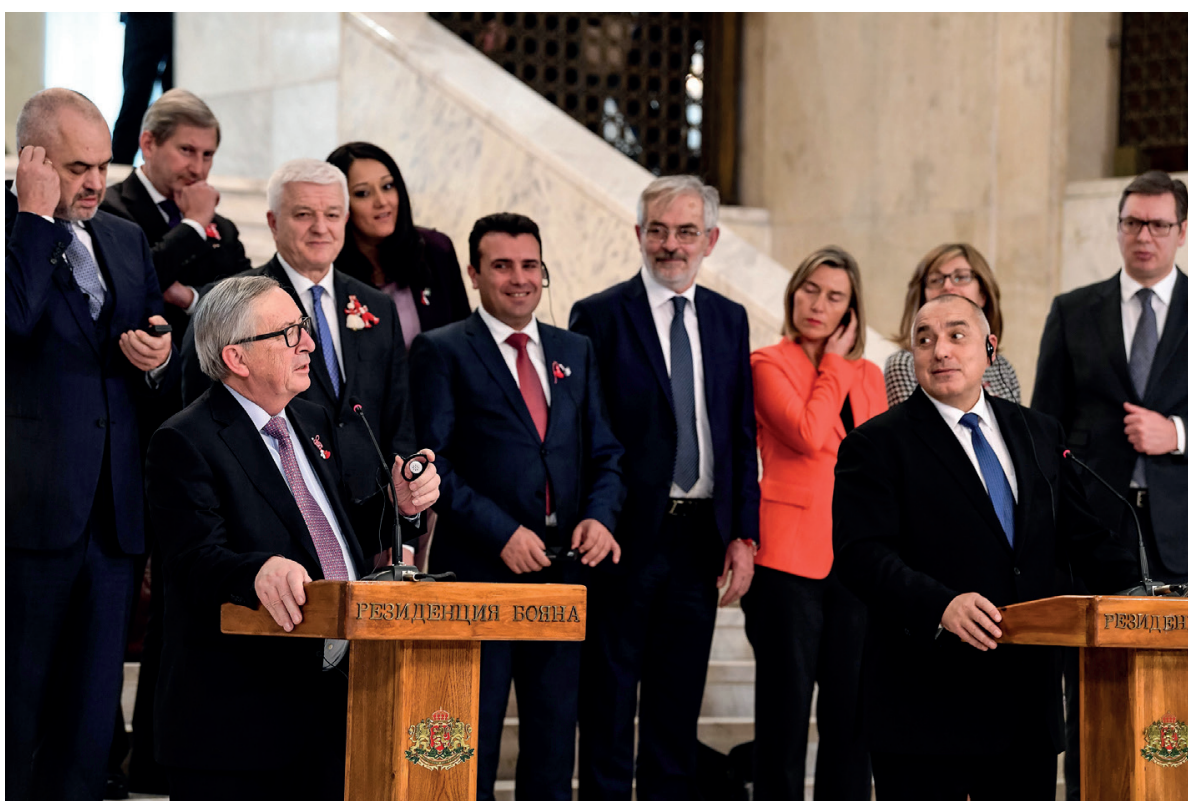

it reinforces the regional countries' potential accession into the EU. Therefore, despite the stagnation, there seems to be a division of labor when it comes to the transatlantic community's engagement of the Western Balkans. While the NATO membership trajectory promotes technical and military reforms using NATO's comparative advantage, the EU membership trajectory promotes political and economic reforms in the region based on the EU's comparative advantage.

Much like the recent resolution of the name dispute between Greece and North Macedonia, a potential normalization of bilateral relations between Kosovo and Serbia would remove a significant barrier against EU accession and provide notable positive momentum in the transatlantic integration of the region. However, the two sides should be presented with greater incentives to achieve mutual recognition of each other's sovereignty, as spoilers are eager to undermine the dialogue. ${ }^{48}$ It is imperative that the countries in the region work toward resolving their outstanding bilateral disputes and engage in further regional cooperation, as indicated in the Strategy document.

Having said that, the timeframe announced by the European Commission for Western Balkan EU accession is extremely ambitious; and it is far from certain that any of the countries will be ready for accession in 2025. This, once again, undermines the credibility of the EU accession prospects. For instance, in June 2018, the European Council did not proceed with the decision to open up accession negotiations with Albania and North Macedonia. Moreover, the
Representatives of the Balkan states and EU during a press conference after their Western Balkans'leaders meeting in Sofia on March 1, 2018. DIMITAR DILKOFF / AFP / Getty Images 
Berlin Process did not have a proper budgetary allocation for covering the Western Balkans Summit costs or for financing its initiatives. The financing of transport and energy projects came from the national budgets of the Western Balkan countries, the IPA, the International Financial Institutions (IFI), and through bilateral formulas. ${ }^{49}$ To achieve a concrete step toward transatlantic integration of the countries in the region, there needs to be a more structured financial mechanism.

The fight against terrorism, enhanced border management, and cooperation to combat human trafficking and organized crime are important areas where collaboration between transatlantic actors and the Western Balkans may be enhanced for the mutual benefit of all parties involved. While important documents and roadmaps were agreed upon under the framework of the Berlin Process, the implementation of legislation continues to present a challenge for the parties, due to the rise of populism and Euroscepticism in the EU.

Additionally, the EU accession process must be modified, and become a more active and multi-layered process. The Berlin Process was a great start, but it needs to be expanded to cover additional issue areas for cooperation, such as greater scrutiny on rule of law or a greater voice for the civil society and people-to-people networks. Similarly, as a new European Commission is set to come to charge in May 2019, it is not clear whether the EU accession trajectory will remain a priority.

The political elites in the region need to be convinced to work toward transatlantic integration. It will be especially difficult for the countries in the region to stay the course towards democratization while many in the EU go through their own crises of democracy and experience a rise of populism and ultra-nationalism. Political willingness to engage in a more constructive reform process with the transatlantic infrastructures emerges as a key factor in explaining successful transatlantic integration. Developments since the election of a new government in North Macedonia appropriately illustrate this point, as the country made great strides in its reform process to bring itself closer to NATO and EU accession.

If the EU and NATO are unwilling or incapable of taking on a leading role, other regional actors might be willing to step in to fill the strategic vacuum that was created by the EU from 2004 to 2014. Some outside powers, such as China, Russia, Turkey, and a number of Gulf states, have maintained a more active regional presence since 2010. As a result of the recent revival of the rivalry between NATO and Russia, Russia is paying extra attention to the region in order to preserve its sphere of influence due to the cultural and historical ties it has with Orthodox Slavs and to prevent the Euro-Atlantic, and especially the NATO integration of the countries in the region. Russian President Pu- 
tin perceives NATO enlargement as hostile to Russian interests and was quoted as saying that Russia perceives "the policy of NATO expansion as a remnant of the Cold War and an erroneous and destructive military and political strategy." ${ }^{50}$

Due to its close ties with Russia, Serbia, for instance, has refused to implement EU sanctions against Russia in response to the illegal Russian annexation of Crimea. Serbian President Vučić received a state medal from Russia in January 2019, given to Russian civil servants and foreign officials who have contributed to maintaining good relations with Russia. While Serbia tries to strike a fine balance between its EU accession aspirations and traditional links to Russia, it will have to tackle the difficult issue of choosing one side over the other by 2025 .

Russia also maintains important ties with Montenegro, North Macedonia, and Bosnia and Herzegovina due to the presence of Serb minorities in these countries. The coup attempt to replace the government in Montenegro with a pro-Russian government in October 2016 had a chilling effect in transatlantic circles and indicated how far the Russians were willing to go to avert the NATO accession of Montenegro.

Finally, the absence of hot conflict should not be equated with positive peace. There are still many unresolved conflicts and an increasing appetite for irredentism and secessionism. To illustrate, Russia has been a key supporter of Republika Srpska's secessionist aspirations. Russian propaganda outlets are trying to take advantage of the situation to engage in campaigns against the EU and NATO. As indicated in the progress reports by the European Commission, media independence is shrinking in all of the Western Balkan countries, making it difficult for the citizens of these countries to receive objective information. In order to counter the spoiler role that Russia and other outside powers seek to play in the region, the EU and NATO should improve their coordination on attempts to resolve outstanding issues and re-energize the enlargement process. The two organizations should make explicit declarations about the importance of preserving the integrity of territorial borders.

Euro-Atlantic integration and the enlargement of the EU and NATO are pathways to maintaining stability and peace, and establishing democracy in the Western Balkans. Strengthening the rule of law, democracy, good governance, 
and economic progress, engaging in public administration reform and the fight against corruption and organized crime, and encouraging regional connectivity and cooperation are important steps toward a transatlantic future. It remains to be seen how decisively and effectively the transatlantic actors and the countries in the Western Balkans will commit to making progress toward that future.

\section{Endnotes}

1. "Partnership for Peace Programme," NATO, (June 7, 2017), retrieved April 29, 2019, from https://www. nato.int/cps/en/natohq/topics_50349.htm.

2. "Western Balkans Labor Market Trends 2018," World Bank, (March 2018), retrieved April 29, 2019, from http://documents.worldbank.org/curated/en/565231521435487923/pdf/124354-WP-P158508-PUBLIC-16-3-2018-10-13-39-WBLabormarkettrends.pdf.

3. "Western Balkans Labor Market Trends 2018."

4. "Western Balkans Labor Market Trends 2018."

5. While at first sight, this may seem to be in line with the assumptions of securitization theory, it is important to underline that there are genuine security interests on the part of the transatlantic allies with regards to the Western Balkans, making securitization argument rather irrelevant in this context.

6. The only exception to this is Serbia, as the country aspires to preserve its military neutrality and prefers to stay outside of NATO.

7. "EU-Western Balkans Summit Thessaloniki, 21 June 2003 Declaration," European Council, 10229/03 (Presse 163), (June 21, 2003).

8. Slovenia was among the ten Central and Eastern European countries that were admitted into the EU in 2004.

9. Croatia was the second former Yugoslav republic admitted into the EU.

10. "Riga Summit Declaration," NATO, (November 29, 2006), retrieved April 29, 2019, from www.nato.int/ docu/pr/ 2006/p06-150e.htm.

11. "Bucharest Summit Declaration," NATO, (April 3, 2008), retrieved April 29, 2019, from www.nato.int/ docu/pr/2008/p08-049e.html.

12. Ronald Linden (ed.), Norms and Nannies: The Impact of International Organizations on the Central and Eastern European States, (Lanham, MD: Rowman and Littlefield, 2002), one of the earliest works on conditionality, defines it as the power of the EU to generate pressure on the applicant countries to conform to the expectations of democratic societies and competitive markets.

13. See, Frank Schimmelfennig and Hanno Scholtz, "Legacies and Leverage: EU Political Conditionality and Democracy Promotion in Historical Perspective," Europe-Asia Studies, Vol. 62, No. 3 (May 2010), pp. 457-458, for a detailed overview of the vast literature on conditionality.

14. Robert Keohane, Stephen Macedo, and Andrew Moravcsik, "Democracy-Enhancing Multilateralism," International Organization, Vol. 63, No. 1 (2009), pp. 1-31; Jon Pevehouse, Democracy from Above: Regional Organizations and Democratization, (Cambridge: Cambridge University Press, 2005).

15. Iver Neumann and Ole Sending, Governing the Global Polity: Practice, Mentality, Rationality, (Ann Arbor: University of Michigan Press, 2010); Michael Barnett and Martha Finnemore, Rules for the World: International Organizations in Global Politics, (Ithaca, New York: Cornell University Press, 2004).

16. Jeffrey Checkel, "International Institutions and Socialization in Europe: Introduction and Framework," International Organization, Vol. 59, No. 4 (2005), pp. 801-826.

17. Stefan Wolff and Oya Dursun-Özkanca (eds.), External Interventions in Civil Wars: The Role and Impact of Regional and International Organisations, (London, New York: Routledge, 2014). 
18. Simon Chesterman, You, the People: The United Nations, Transitional Administration, and State-building, (Oxford: Oxford University Press, 2004).

19. Oya Dursun-Özkanca and Antoine Vandemoortele, "The European Union and Security Sector Reform: Current Practices and Challenges of Implementation," European Security, Vol. 21, No. 2 (2012), pp. 139-160.

20. Kenneth W. Abbott and Duncan Snidal, "International Regulation without International Government: Improving IO Performance through Orchestration," Review of International Organizations, Vol. 5, No. 3 (2010), pp. 315-344; Bruce Jones and Feryal Cherif, "Evolving Models of Peacekeeping: Policy Implications and Responses," Center on International Cooperation, New York University (September 2003), retrieved April 29, 2019, from http://www.peacekeepingbestpractices.unlb.org; Dan Smith, Towards a Strategic Framework for Peacebuilding: The Synthesis Report of the Joint Utstein Study on Peacebuilding, (Oslo: PRIO, 2003); Oya Dursun-Özkanca, "The Assembly-Line Model of Peacebuilding: Towards a Theory of International Collaboration in Multidimensional Peacebuilding Operations," International Journal of Peace Studies, Vol. 21, No. 2 (2016); Nicola Dahrendorf, "A Review of Peace Operations: A Case for Change," Conflict, Security and Development Group, King's College London, Synthesis Report, (March 10, 2003), retrieved April 29, 2019, from http://www.cmi.no/publications/file/1655-afghanistan-a-snapshot-study; Cedric De Coning, "Coherence and Coordination in United Nations Peacebuilding and Integrated Missions: A Norwegian Perspective," Norwegian Institute of International Affairs, Security in Practice 5 (2007), retrieved April 29, 2019, from http://www.nupi.no/layout/set/print/content/download/2661/49599/ version/3/file/de+Coning-Security+in+Practice+no.+5.pdf; Wolff and Dursun-Özkanca (eds.), External Interventions in Civil Wars.

21. John Mearsheimer, "The False Promise of International Institutions," International Security, Vol. 19, No. 3 (2005), pp. 5-49.

22. Lisa Martin and Beth Simmons, "Theories and Empirical Studies of International Organizations," International Organization, Vol. 52, No. 4 (1998), pp. 729-757; Robert Keohane and Joseph Nye, Power and Interdependence, (New York: Harper Collins, 1989); Robert Keohane, After Hegemony: Cooperation and Discord in the World Economy, (Princeton: Princeton University Press, 1984); Robert Axelrod and Robert Keohane, "Achieving Cooperation under Anarchy: Strategies and Institutions," World Politics, Vol. 38, No. 1 (1985), pp. 226-254; Robert Keohane and Lisa Martin, "The Promise of Institutionalist Theory," International Security, Vol. 20, No. 1 (1995), pp. 39-51.

23. Lisa Martin, Coercive Cooperation: Explaining Multilateral Economic Sanctions, (Princeton: Princeton University Press, 1992).

24. Keohane, Macedo, and Moravcsik, "Democracy-Enhancing Multilateralism."

25. Stephen Krasner, (ed.), International Regimes, (Ithaca, NY: Cornell University Press, 1983).

26. Elinor Ostrom, "New Horizons in Institutional Analysis," American Political Science Review, Vol. 89, No. 1 (1995), pp. 174-178.

27. Thorsten Benner and Philipp Rotmann, "Learning to Learn?: UN Peacebuilding and the Challenges of Building a Learning Organization," Journal of Intervention and Statebuilding, Vol. 2, No. 1 (2008), pp. 4362; Susanna Campbell, "When Process Matters: The Potential Implications of Organizational Learning for Peacebuilding Success," Journal of Peacebuilding and Development, Vol. 4, No. 2 (2008), pp. 20-32; Anna Fosdick, "Conflict Management Learning? Policy Reflections and Institutional Reforms," Global Governance, Vol. 5, No. 4 (1999), pp. 425-455.

28. Boyka Stefanova, "OSCE and Balkan Security," Journal of Balkan and Near Eastern Studies, Vol. 11, No. 1 (2009), pp. 43-60; Margaret Keck and Kathryn Sikkink, Activists Beyond Borders: Advocacy Networks in International Politics, (Ithaca, NY: Cornell University Press, 1998).

29. David Ricardo, On the Principles of Political Economy and Taxation, $3^{\text {rd }}$ Edition, (London: John Murray, 1817); Adam Smith, An Inquiry into the Nature and Causes of the Wealth of Nations, (London: Methuen \& Co., Ltd, 1776).

30. Dursun-Özkanca, "The Assembly-Line Model of Peacebuilding."

31. "Macedonia Referendum: Name Change Vote Fails to Reach Threshold," BBC World News, (October 1, 2018), retrieved from https://www.bbc.com/news/world-europe-45699749. 
32. Nikolaos Tzifakis, "What the Ratification of the Prespa Agreement Means for Greek Politics," LSE Blog, (January 30, 2019), retrieved April 29, 2019, from http://blogs.lse.ac.uk/europpblog/2019/01/30/ what-the-ratification-of-the-prespa-agreement-means-for-greek-politics/.

33. Donika Emini and Isidora Stakić, "Belgrade and Pristina: Lost in Normalisation?" European Union Institute for Security Studies, (April 2018), retrieved April 29, 2019, from https://www.iss.europa.eu/sites/ default/files/EUISSFiles/Brief\%205\%20Belgrade\%20and\%20Pristina.pdf.

34. "Serbia 2018 Report," European Commission, Communication from the Commission to the European Parliament, the Council, the European Economic and Social Committee and the Committee of the Regions, SWD (2018) 152 final, (April 7, 2018), retrieved April 29, 2019, from https://ec.europa.eu/neighbourhood-enlargement/sites/near/files/20180417-serbia-report.pdf, p. 4.

35. "Kosovo Imposes 100-Percent Tariff on Serbian Goods," France24, (November 21, 2018), retrieved from https://www.france24.com/en/20181121-kosovo-imposes-100-percent-tariff-serbian-goods.

36. "Membership Action Plan," NATO, (February 18, 2019), retrieved April 29, 2019, from https://www. nato.int/cps/ua/natohq/topics_37356.htm.

37. "Membership Action Plan."

38. "Overview: Instrument for Pre-Accession Assistance," European Commission, European Neighbourhood Policy and Enlargement Negotiations, retrieved April 29, 2019, from https://ec.europa.eu/neighbourhood-enlargement/instruments/overview_en.

39. "A Credible Enlargement Perspective for and Enhanced EU Engagement with the Western Balkans," European Council, Sofia, COM (2018) 65 final, (June 2, 2018).

40. "Western Balkans Summit 2017: Delivering for the Region," European Commission, (July 12, 2017), retrieved April 29, 2019, from https://ec.europa.eu/transport/themes/international/news/2017-07-12western-balkans-summit-2017-delivering-region_en.

41. "Chair's Conclusions of the Heads' Meeting of the London Western Balkans Summit," Western Balkans Summit, (July 10, 2018), retrieved April 29, 2019, from https://assets.publishing.service.gov.uk/government/uploads/system/uploads/attachment_data/file/724295/Heads_Meeting_-_Chair_s_Conclusions. pdf.

42. "Chair's Conclusions of the Heads' Meeting of the London Western Balkans Summit."

43. "A Credible Enlargement Perspective for and Enhanced EU Engagement with the Western Balkans."

44. "Strategy for the Western Balkans: EU Sets Out New Flagship Initiatives and Support for the Reform-Driven Region," European Commission, (February 8, 2018), retrieved April 29, 2019, from http:// europa.eu/rapid/press-release_IP-18-561_en.htm.

45. Richard Grieveson, Julia Grübler, and Mario Holzner, “Western Balkans'EU Accession: Is the 2025 Target Date Realistic?" The Vienna Institute for International Economic Studies, Policy Notes/Reports 22 (May 2018), retrieved April 29, 2019, from https://wiiw.ac.at/western-balkans-eu-accession-is-the-2025-target-date-realistic--dlp-4526.pdf.

46. "Strategy for the Western Balkans."

47. Ivan Vejvoda, "The Balkans: No War in Sight," The German Marshall Fund of the United States, (February 17, 2016), retrieved April 29, 2019, from http://www.gmfus.org/commentary/balkans-no-war-sight.

48. Michael Carpenter and Mieczysław P. Boduszyński, "Does the West Have a Vision for the Western Balkans?" War on the Rocks, (April 13, 2018), retrieved April 29, 2019, from https://warontherocks. com/2018/04/does-the-west-have-a-vision-for-the-western-balkans/.

49. "The Berlin Process 2014-2018," Cooperation \& Development Institute, (March 2018), retrieved April 29, 2019, from http://cdinstitute.eu/web/wp-content/uploads/2018/03/The-Berlin-Process-2014-2018.pdf.

50. "Ahead of Serbia Visit, Putin Claims US Is Playing Destabilizing Role in Balkans," Radio Free Europe/ Radio Liberty, (January 16, 2019), retrieved from https://www.rferl.org/a/putin-serbia-interviews-us/ 29712614.html. 